[Original]

\title{
Involvement of TLR4 in Diazinon-Induced Neurotoxicity in Mice
}

\author{
Tin-Tin WIN-Shwe ${ }^{1}$, Daisuke NAKaJma ${ }^{2}$ and Hidekazu FuJIMAKI ${ }^{2}$ \\ ${ }^{1}$ Center for Environmental Health Sciences, National Institute for Environmental Studies, \\ Onogawa, Tsukuba, Ibaraki 305-8506, Japan \\ ${ }^{2}$ Center for Environmental Risk Research, National Institute for Environmental Studies, Onogawa, \\ Tsukuba, Ibaraki 305-8506, Japan
}

\begin{abstract}
Our laboratory recently reported that Toll-like receptor (TLR) 4 may play a role in the neurotoxic effects in mice exposed to the environmental toxic chemical toluene. To investigate the role of TLR4 in hippocampal neurotrophin expression, C3H/HeN (TLR4 intact) and $\mathrm{C} 3 \mathrm{H} / \mathrm{HeJ}$ (TLR4 defective) male adult mice were administered diazinon (0, 0.05 , 0.5 or $5 \mathrm{mg} / \mathrm{kg}$ ) intraperitoneally once a week for three weeks. Twenty-four hours after the final diazinon injection, the hippocampus was collected from each mouse to detect mRNA expression of neurotrophins (nerve growth factor (NGF) and brain-derived neurotrophic factor (BDNF)) by the real-time RT-PCR method. There was no difference between groups in neurotrophin expression in the $\mathrm{C} 3 \mathrm{H} / \mathrm{HeN}$ mice. However, the expression of NGF and BDNF mRNAs was suppressed significantly in the diazinon-injected $\mathrm{C} 3 \mathrm{H} / \mathrm{HeJ}$ mice compared with their control group. We also found an increased tendency of proinflammatory chemokine CCL3 mRNA and a marked increase in the proapoptotic gene Bax mRNA in the diazinoninjected $\mathrm{C} 3 \mathrm{H} / \mathrm{HeJ}$ mice. Our findings indicate that diazinon injection affects neurotrophin expression in the hippocampus in TLR4-defective mice but not in TLR4 intact mice. These results suggest that a defective TLR4 signaling pathway in the mouse hippocampus can be easily affected by diazinon administration.
\end{abstract}

Key words : toll-like receptor 4, diazinon, neurotrophins, neurotoxicity, hippocampus.

(Received August 10, 2011, accepted January 25, 2012) 


\section{Introduction}

Innate immunity is the primary response in protecting the body from microorganisms that are identified through molecular patterns recognized by Toll-like receptor (TLR). Among the TLRs, TLR4 is expressed in a wide range of nervous system cell types, such as microglia, astrocytes, oligodendrocytes, and neurons [1-6]. TLR4 is crucial for the identification of lipopolysaccharides (LPS) present in the cell wall component of Gram-negative bacteria [7, 8]. The binding of LPS to its cognate TLR4 triggers the nuclear factor kappa-light-chain-enhancer of activated B cells $(\mathrm{NF}-\mathrm{\kappa} \mathrm{B})$ transduction pathway, leading to the transcriptional activation of proinflammatory cytokines, chemokines and other genes essential for pathogen elimination [9, 10]. Although the role of TLR4 signaling in airway pathogenesis has been extensively demonstrated, the role of TLR4 in brain function after pesticide exposure remains unclear.

Since 1965, organophosphate pesticides (OPs) have been used extensively as agricultural and commercial pesticides [11]. OPs were originally thought to interfere with brain development through their inhibitory action on cholinesterase, but it has become evident that other noncholinergic mechanisms are involved in OP developmental neurotoxicity [12]. Chlorpyrifos is the most commonly used OP and there are many reports indicating the consequences of brain functions after exposure to it. However, little is known about the effects of another commonly used OP, diazinon, on neurobehavioral and neurochemical changes in brain regions, and its mechanism of action is still unclear. We suggest that further searches for biomarkers of neurotoxicity to acetylcholine esterase inhibition should be undertaken to account for the complexity of the effects triggered by exposure to diazinon.

Although diazinon has been banned in the US since 2004, it is still heavily used in Japan not only in the agricultural field, but also in home gardening and indoor pest control. The exposure route of diazinon may be breathing, eating, drinking or by skin contact [13]. In Japan, the concentrations of diazinon are $<1.0 \sim 3.3 \mathrm{ng} / \mathrm{m}^{3}$ and $<1.0 \sim 1.8 \mathrm{ng} / \mathrm{m}^{3}$ in indoor air and outdoor air, respectively [14].

A recent study suggests that TLRs might not only serve to sense microbial pathogen-associated molecular patterns (PAMPs), but also to sense certain endogenous factors that act as damageassociated molecular pattern (DAMP) molecules [15]. Potential DAMP molecules include heat shock proteins, fibrinogen, fibronectin, heparin sulfate, soluble hyaluronan, oxidized low density lipoprotein (LDL), gangliosides, fatty acids and other cues of dying cells, and these molecules can stimulate TLR4 and TLR2 signaling [16-21]. We hypothesized that diazinon may act directly or indirectly via TLR4 to induce neuroinflammation and then affect neurotrophin expression because neurtophin acts as an important neuroimmune mediator in the brain.

The hippocampus is important in the formation of recognition memory in both humans and animals $[22,23]$. The N-methyl-D-aspartate (NMDA) type of glutamate receptors in the hippocampus has been reported to be essential for spatial learning and memory as well as for the induction of synaptic plasticity [24, 25]. Recently, our laboratory has reported that acute toluene injection impaired hippocampus-dependent nonspatial memory retention in a novel object recognition task accompanied by selective modulation of the NMDA receptor subunit expression [26]. 
The target site and signaling pathway in the brain for a specific environmental chemical may be different. Therefore, in the present study, we focused on the involvement of TLR4 in the effects of diazinon exposure on the expression of neurotrophins, their receptors and NMDA receptor subunits in TLR4 intact $\mathrm{C} 3 \mathrm{H} / \mathrm{HeN}$ and TLR4 defective $\mathrm{C} 3 \mathrm{H} / \mathrm{HeJ}$ adult mice.

\section{Materials and Methods}

\section{Animals}

Male C3H/HeN (TLR4 intact) and C3H/HeJ (TLR4 defective) mice (7 weeks old) were purchased from Charles River Japan, Inc. (Tokyo, Japan). At the age of 8 weeks, mice were recruited in the experiments. The mice were housed in cages under controlled environmental conditions (temperature $23 \pm 0.5^{\circ} \mathrm{C}$, humidity $50 \pm 5 \%$, lights on 07:00-19:00 h). The experiments were conducted under the control of the Ethics Committee of Animal Care and Experimentation of the National Institute for Environmental Studies, Japan.

Administration of diazinon. Male $\mathrm{C} 3 \mathrm{H} / \mathrm{HeN}$ or $\mathrm{C} 3 \mathrm{H} / \mathrm{HeJ}$ mice were administered diazinon $[0.05$ $\mathrm{mg} / \mathrm{kg}(\mathrm{n}=5), 0.5 \mathrm{mg} / \mathrm{kg}(\mathrm{n}=5)$ or $5 \mathrm{mg} / \mathrm{kg}(\mathrm{n}=5)]$ intraperitoneally once a week for three weeks. Slotkin and colleagues used a 1 to $2 \mathrm{mg} / \mathrm{kg}$ dose of diazinon in neonatal rats, which is below the threshold for systemic toxicity or growth impairment, and which spans the threshold for barely detectable cholinesterase inhibition [27]. Therefore, in the present study we selected $0.05,0.5$, or $5 \mathrm{mg} / \mathrm{kg}$ as a suitable dose of diazinon in adult mice. The diazinon (Wako Pure Chemicals, Osaka, Japan) was dissolved in $0.01 \%$ dimethyl sulfoxide (DMSO) with normal saline and injected in a volume of $200 \mu \mathrm{l}$. Control mice were injected with vehicle only $(\mathrm{n}=5)$.

Analysis of the expression level of neurotrophins, their receptors and memory function-related gene in the hippocampus

We used a previously described protocol to collect the total RNA from the hippocampal samples [28]. Briefly, total RNA extraction from the hippocampal samples was performed using the BioRobot EZ-1 and EZ-1 RNA tissue mini kits (Qiagen GmbH, Germany). Then the purity of the total RNA was examined and the quantity was estimated using the ND-1000 NanoDrop RNA Assay protocol (NanoDrop, USA). Next we performed first-strand cDNA synthesis from the total RNA using SuperScript RNase $\mathrm{H}^{-}$Reverse Transcriptase II (Invitrogen, USA), according to the manufacturer's protocol. Next we examined the hippocampal mRNA expressions of $18 \mathrm{~S}$ (forward $5^{\prime}$ -TACCACATCCAAGAAGGCAG-3', reverse 5'-TGCCCTCCAATGGATCCTC-3'), nerve growth factor (NGF) (forward 5'-TGGGCTTCAGGGACAGAGTC-3', reverse 5'-CAGCTTTCTATACTGGCCGCAG-3'), brain-derived neurotrophic factor (BDNF): ID_12064, tropomyosin-related kinase (Trk)A: ID_18211, TrkB: ID_18212, memory function-related gene NMDA receptor subunits such as NR1: ID_14810, NR2A: ID_14811, and NR2B: ID_14812, and proinflammatory cytokines such as tumor necrosis factor (TNF)- $\alpha$ : (forward 5'-GGTTCCTTTGTGGCACTTG-3', reverse 5'-TTCTCTTGGTGACCGGGAG-3') CCL2: (forward 5'-ATGAGTAGCAGCAGGTGAGTG-3', reverse 5'-GTCCCTGTCATGCTTCTGG-3'), CCL3: (forward 5'-TGAATTGGCGTGGAATCTTC-3', reverse 5'-TGCAACCAAGTCTTCTCAGC-3'), apoptosis re- 
lated genes such as Bbc3: ID_170770, Bax (the Bcl-2 associated X protein): ID_12028 using a quantitative real-time RT-PCR method and the Applied Biosystems (ABI) Prism 7000 Sequence Detection System (Applied Biosystems Inc., USA). The tissue 18S rRNA level was used as the internal control. Data were analyzed using the comparative threshold cycle method. Then the relative expression level of each gene was individually normalized to the $18 \mathrm{~S}$ rRNA content in the respective samples and expressed as mRNA signals per unit 18S rRNA expression.

\section{Statistical Analysis}

The results of each group were calculated and expressed as the mean \pm standard error (SE). Body weight and various organ weights were analyzed using a one-way analysis of variance (ANOVA). Data from mRNA expressions of neurotrophins and NMDA receptor subunits were also analyzed using a one-way ANOVA followed by a Bonferroni post hoc test. A $P$ value $<0.05$ was considered statistically significant. The statistical analysis was performed using the Statcel 2 statistical analysis system for Microsoft Excel, Version 5.0 (Nankodo Inc., Tokyo, Japan).

\section{Results}

\section{Body and organ weights}

To determine the general toxicity of diazinon, we measured the body and organ weights of the male $\mathrm{C} 3 \mathrm{H} / \mathrm{HeN}$ and $\mathrm{C} 3 \mathrm{H} / \mathrm{HeJ}$ mice at the time of sampling (Table 1). In the $\mathrm{C} 3 \mathrm{H} / \mathrm{HeN}$ mice, apart from the spleen and liver, the body weight and relative organ weights of the brain, thymus,

Table 1. Body and organ weights of male $\mathrm{C} 3 \mathrm{H} / \mathrm{HeN}$ and $\mathrm{C} 3 \mathrm{H} / \mathrm{HeJ}$ mice after exposure to diazinon

\begin{tabular}{|c|c|c|c|c|c|c|}
\hline Strain & & Body weight (g) & Spleen (mg) & Lung (mg) & Thymus (mg) & Liver (mg) \\
\hline \multirow{4}{*}{$\mathrm{HeN}$} & Control & $26.5 \pm 0.7$ & $76.9 \pm 3.5$ & $53.1 \pm 1.1$ & $27.9 \pm 2.4$ & $1329.0 \pm 62.4$ \\
\hline & $0.05 \mathrm{mg} / \mathrm{Kg}$ & $28.4 \pm 0.0$ & $102.4 \pm 3.5^{* *}$ & $50.9 \pm 2.4$ & $26.1 \pm 1.6$ & $1594.0 \pm 49.4 * *$ \\
\hline & $0.5 \mathrm{mg} / \mathrm{Kg}$ & $25.9 \pm 0.5$ & $80.6 \pm 2.1 \dagger \dagger$ & $51.1 \pm 5.6$ & $27.3 \pm 2.3$ & $1366.4 \pm 29.2$ \\
\hline & $5.0 \mathrm{mg} / \mathrm{Kg}$ & $28.2 \pm 0.6$ & $74.6 \pm 1.0 \dagger \dagger$ & $52.4 \pm 3.5$ & $28.8 \pm 1.2$ & $1480.0 \pm 30.2 \dagger$ \\
\hline \multirow{4}{*}{$\mathrm{HeJ}$} & Control & $25.5 \pm 0.5$ & $85.3 \pm 4.5$ & $51.2 \pm 3.6$ & $33.2 \pm 2.3$ & $1235.6 \pm 53.9$ \\
\hline & $0.05 \mathrm{mg} / \mathrm{Kg}$ & $25.4 \pm 0.6$ & $84.1 \pm 3.2$ & $58.0 \pm 6.0$ & $33.4 \pm 2.2$ & $1210.8 \pm 31.9$ \\
\hline & $0.5 \mathrm{mg} / \mathrm{Kg}$ & $24.3 \pm 0.3$ & $77.6 \pm 2.2$ & $46.1 \pm 0.7$ & $33.9 \pm 1.8$ & $1109.4 \pm 29.9$ \\
\hline & $5.0 \mathrm{mg} / \mathrm{Kg}$ & $25.0 \pm 0.4$ & $80.4 \pm 5.8$ & $44.8 \pm 0.8$ & $24.5 \pm 1.7 *+9$ & $1191.0 \pm 38.0$ \\
\hline \multicolumn{2}{|l|}{ Strain } & Brain (mg) & $\mathrm{OB}(\mathrm{mg})$ & Hippo (mg) & Kidney (mg) & Testis (mg) \\
\hline \multirow{4}{*}{$\mathrm{HeN}$} & Control & $442.8 \pm 6.8$ & $12.0 \pm 0.8$ & $17.0 \pm 0.7$ & $199.3 \pm 12.2$ & $77.8 \pm 4.8$ \\
\hline & $0.05 \mathrm{mg} / \mathrm{Kg}$ & $432.6 \pm 4.3$ & $11.0 \pm 0.7$ & $18.6 \pm 0.9$ & $224.4 \pm 8.8$ & $85.0 \pm 2.6$ \\
\hline & $0.5 \mathrm{mg} / \mathrm{Kg}$ & $431.6 \pm 6.3$ & $10.2 \pm 0.2$ & $17.0 \pm 0.6$ & $198.9 \pm 11.7$ & $84.4 \pm 1.4$ \\
\hline & $5.0 \mathrm{mg} / \mathrm{Kg}$ & $431.4 \pm 4.8$ & $10.2 \pm 0.7$ & $17.0 \pm 0.8$ & $212.8 \pm 8.3$ & $84.0 \pm 3.8$ \\
\hline \multirow{4}{*}{$\mathrm{HeJ}$} & Control & $423.6 \pm 2.5$ & $9.6 \pm 1.0$ & $16.8 \pm 0.6$ & $192.0 \pm 5.4$ & $82.4 \pm 1.1$ \\
\hline & $0.05 \mathrm{mg} / \mathrm{Kg}$ & $413.6 \pm 6.2$ & $10.0 \pm 0.3$ & $17.2 \pm 0.7$ & $185.5 \pm 7.1$ & $82.4 \pm 3.2$ \\
\hline & $0.5 \mathrm{mg} / \mathrm{Kg}$ & $413.2 \pm 5.6$ & $8.8 \pm 0.2$ & $15.6 \pm 0.6$ & $179.7 \pm 4.1$ & $82.2 \pm 1.7$ \\
\hline & $5.0 \mathrm{mg} / \mathrm{Kg}$ & $407.6 \pm 3.5$ & $10.2 \pm 0.5$ & $16.4 \pm 0.7$ & $187.0 \pm 8.5$ & $77.2 \pm 2.4$ \\
\hline
\end{tabular}

Data represent the mean \pm SEM of five mice per group, $*: P<0.05$ versus control, $* *: P<0.01$ versus control, $\dagger: P<0.05$ versus $0.05 \mathrm{mg} / \mathrm{Kg}$, $\dagger: P<0.01$ versus $0.05 \mathrm{mg} / \mathrm{Kg}, \quad$ If $P<0.05$ versus $0.5 \mathrm{mg} / \mathrm{Kg}$, OB: olfactory bulb, Hippo: hippocampus 
left lung, kidney and testis were not significantly different between the control and the diazinoninjected groups. The spleen and liver from the $0.05 \mathrm{mg} / \mathrm{Kg}$ diazinon-injected $\mathrm{C} 3 \mathrm{H} / \mathrm{HeN}$ mice were larger than those of the control mice $(P<0.01)$. In the $\mathrm{C} 3 \mathrm{H} / \mathrm{HeJ}$ mice, apart from the thymus, the body weight and relative organ weights of the brain, spleen, liver, lung, kidney and testis were not significantly different between the control and the diazinon-injected groups. However, the thymus from the $0.05 \mathrm{mg} / \mathrm{Kg}$ diazinon-injected $\mathrm{C} 3 \mathrm{H} / \mathrm{HeJ}$ mice was smaller than that of the control mice $(P<0.05)$.

Expression of neurotrophin and its receptors in the hippocampus of the control and diazinoninjected mice

We investigated the effect of diazinon on the mRNA expression levels of neurotrophins, such as NGF and BDNF, in the mouse hippocampus. We did not find any significant difference in neurotrophin mRNA expression between the control and diazinon-injected $\mathrm{C} 3 \mathrm{H} / \mathrm{HeN}$ mice (Fig. 1A, C). However, the expression level of NGF and BDNF mRNA was significantly reduced in the diazinon-injected $\mathrm{C} 3 \mathrm{H} / \mathrm{HeJ}$ mice compared to the control groups $(P<0.05)$ (Fig. 1B, D).

Next we examined the mRNA expression of TrkA (a receptor for NGF) and TrkB (a receptor

A

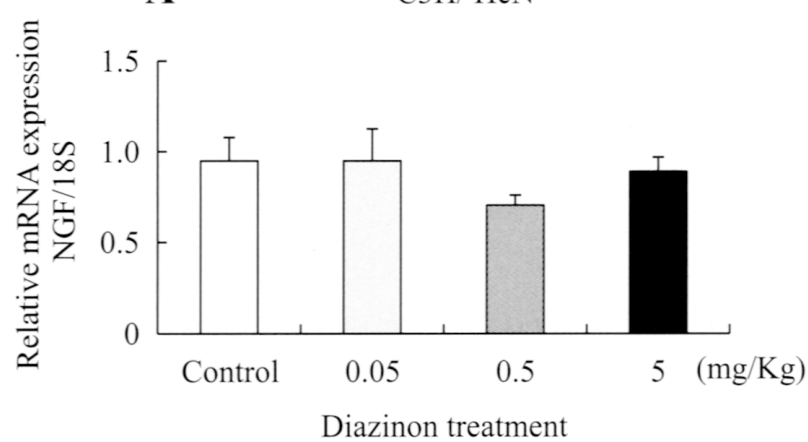

C

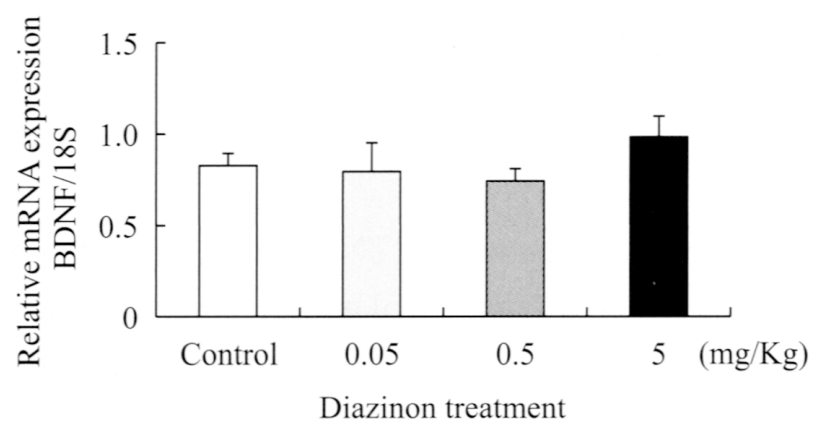

B

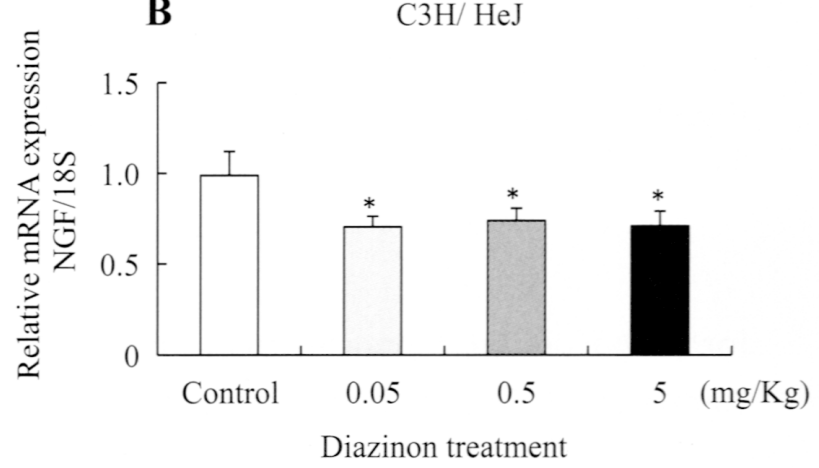

D

$\mathrm{C} 3 \mathrm{H} / \mathrm{HeJ}$

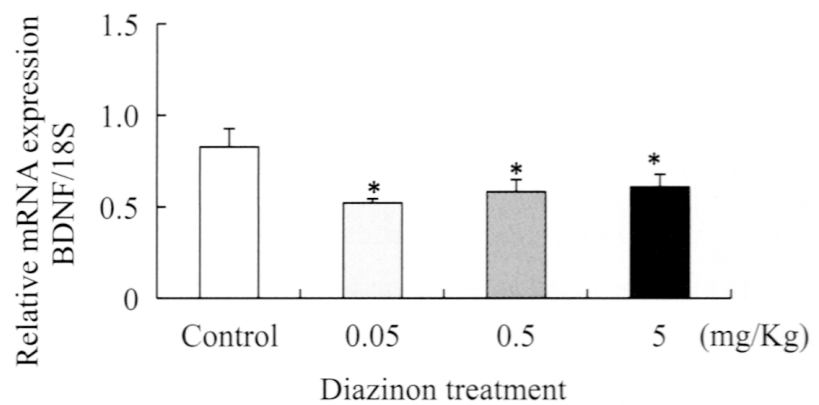

Fig. 1. Neurotrophins, A and B: NGF, C and D: BDNF mRNA expression in the hippocampus of the control and diazinon-injected $\mathrm{C} 3 \mathrm{H} / \mathrm{HeN}$ and $\mathrm{C} 3 \mathrm{H} / \mathrm{HeJ}$ mice. Each bar represents the mean $\pm \mathrm{S} . \mathrm{E} .(\mathrm{n}=5)$ (*: $P<0.05$, compared with the corresponding vehicle-injected group). 


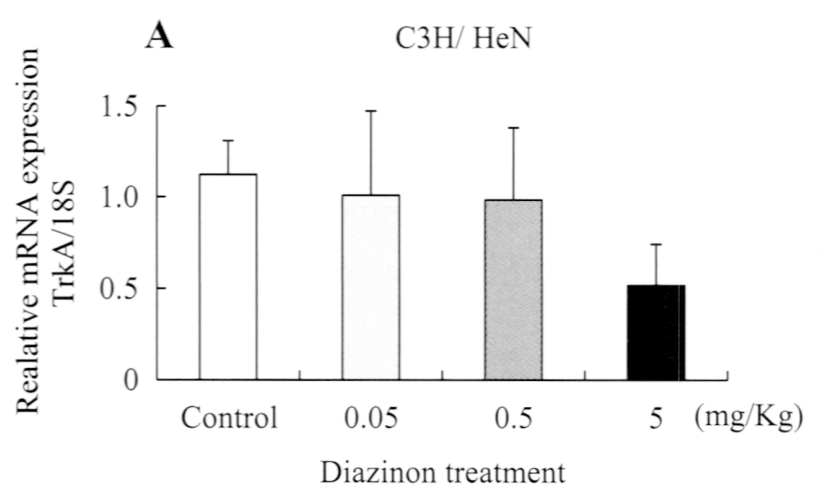

C

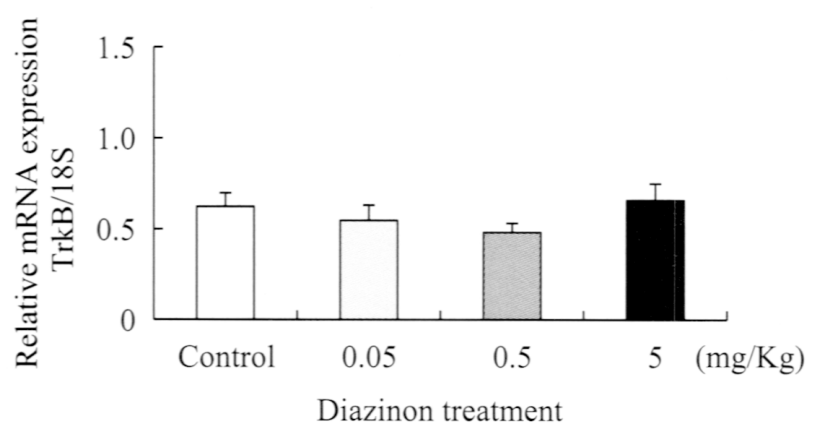

B

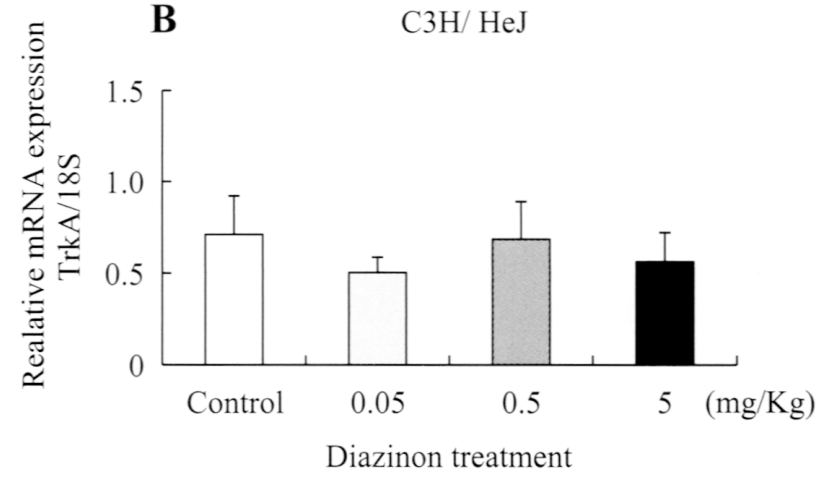

D

$\mathrm{C} 3 \mathrm{H} / \mathrm{HeJ}$

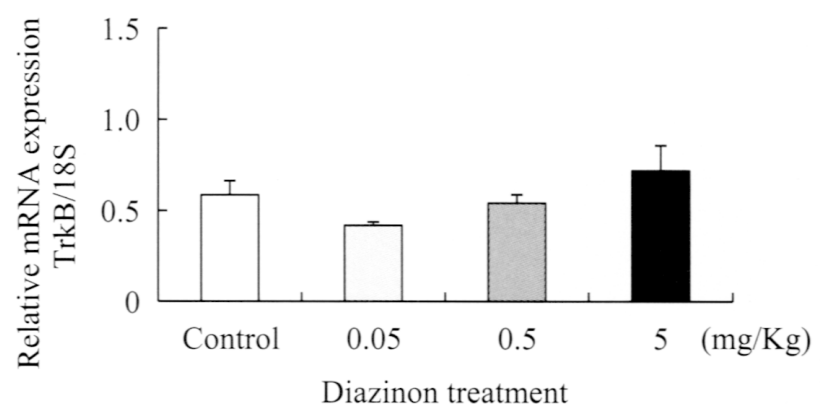

Fig. 2. Neurotrophin receptors, $A$ and $B$ : TrkA, $C$ and $D$ : TrkB mRNA expression in the hippocampus of the control and diazinon-injected $\mathrm{C} 3 \mathrm{H} / \mathrm{HeN}$ and $\mathrm{C} 3 \mathrm{H} / \mathrm{HeJ}$ mice. Each bar represents the mean \pm S.E. $(\mathrm{n}=5)$.

for BDNF) in the hippocampus of the control and diazinon-injected mice. We did not find any significant difference between the groups in both the $\mathrm{C} 3 \mathrm{H} / \mathrm{HeN}$ and $\mathrm{C} 3 \mathrm{H} / \mathrm{HeJ}$ mice (Fig. 2).

Memory function-related gene expression in the hippocampus of the control and diazinon-injected mice

We also examined the mRNA expression of NMDA subunits NR1, NR2A and NR2B in the hippocampus of the control and diazinon-injected mice. We did not find any significant difference between the groups in both the $\mathrm{C} 3 \mathrm{H} / \mathrm{HeN}$ and $\mathrm{C} 3 \mathrm{H} / \mathrm{HeJ}$ mice (Fig. 3).

Proinflammatory cytokine gene expression in the hippocampus of the control and diazinoninjected mice

We also examined the mRNA expression of proinflammatory cytokines TNF- $\alpha$ and potent brain inflammatory mediator CCL2 and CCL3 in the hippocampus of the control and diazinon-injected mice. We did not find any significant difference in TNF- $\alpha$ and CCL2 mRNA expressions between the control and diazinon-injected $\mathrm{C} 3 \mathrm{H} / \mathrm{HeN}$ and $\mathrm{C} 3 \mathrm{H} / \mathrm{HeJ}$ mice (data not shown). In contrast, although not statistically significant CCL3 mRNA expression was dose-dependently increased in the diazinon-injected $\mathrm{C} 3 \mathrm{H} / \mathrm{HeJ}$ mice (Fig. 4A), but not in the $\mathrm{C} 3 \mathrm{H} / \mathrm{HeN}$ mice (data not shown). This indicates that neuroinflammation may have occurred in the diazinon-injected $\mathrm{C} 3 \mathrm{H} / \mathrm{HeJ}$ mice. 
A

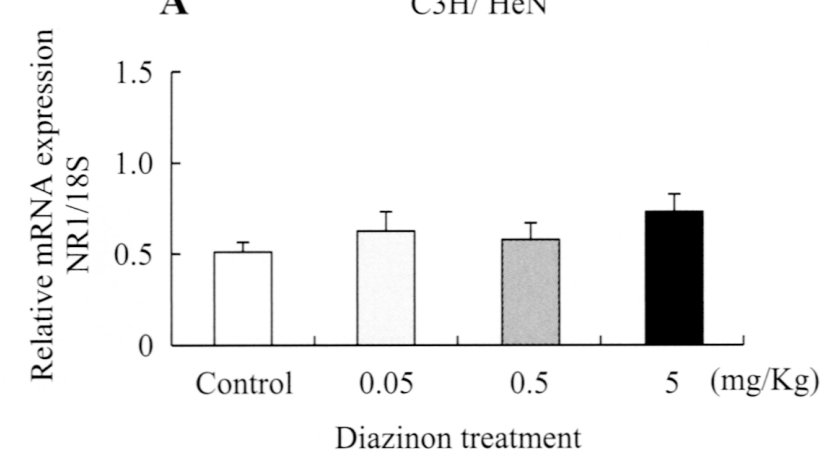

C

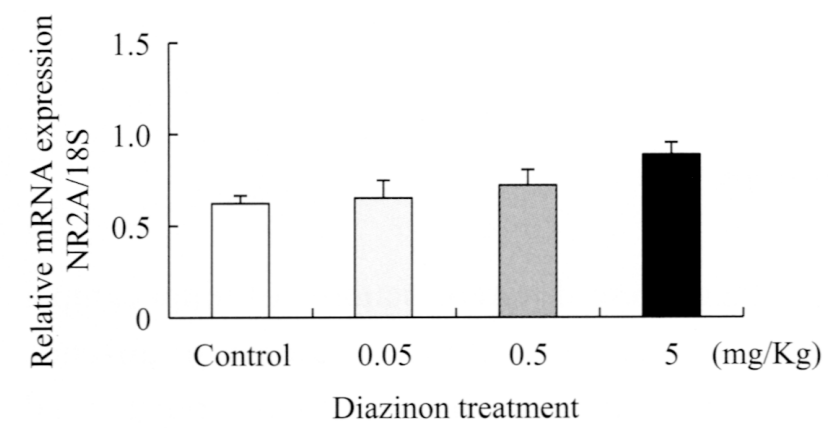

E

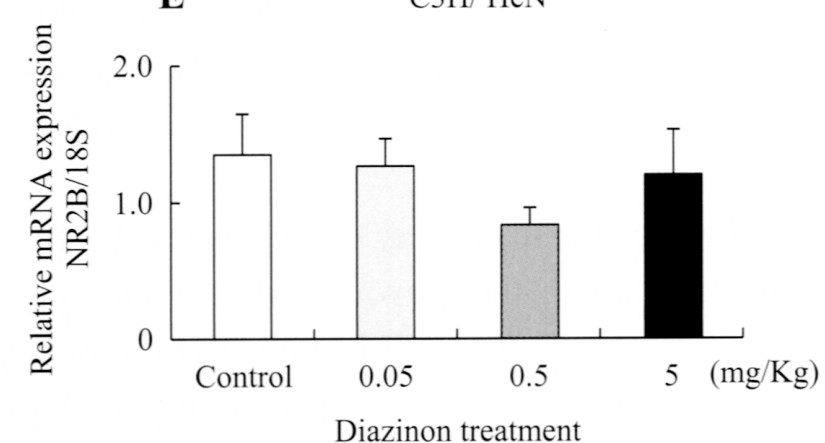

B

C3H/ HeJ

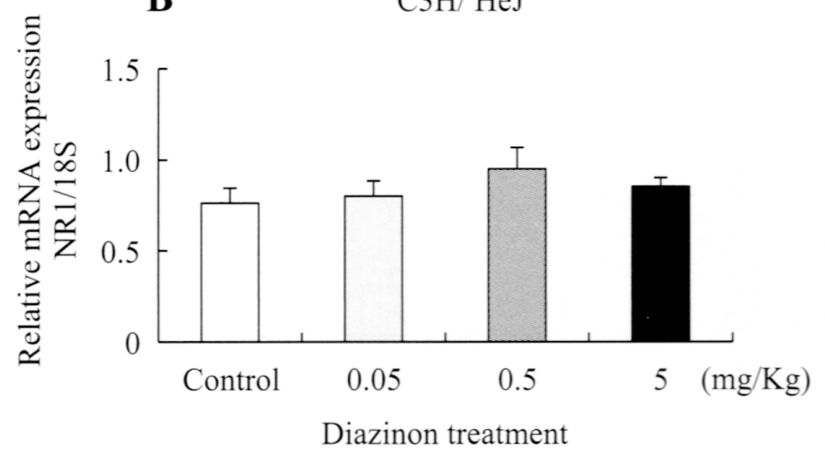

D

C3H/ HeJ

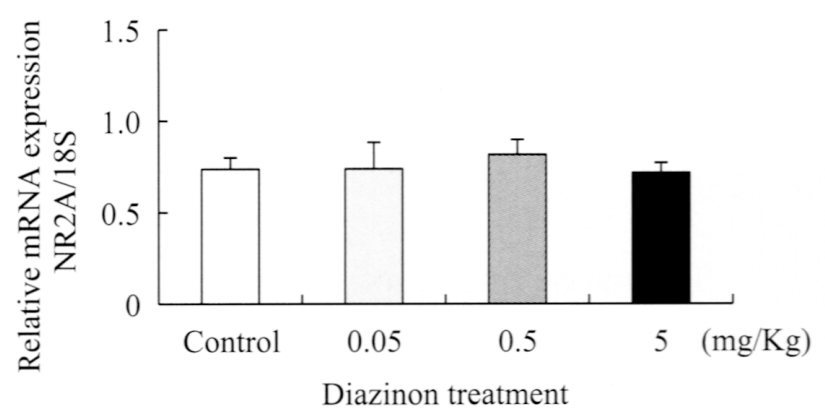

F

C3H/ HeJ

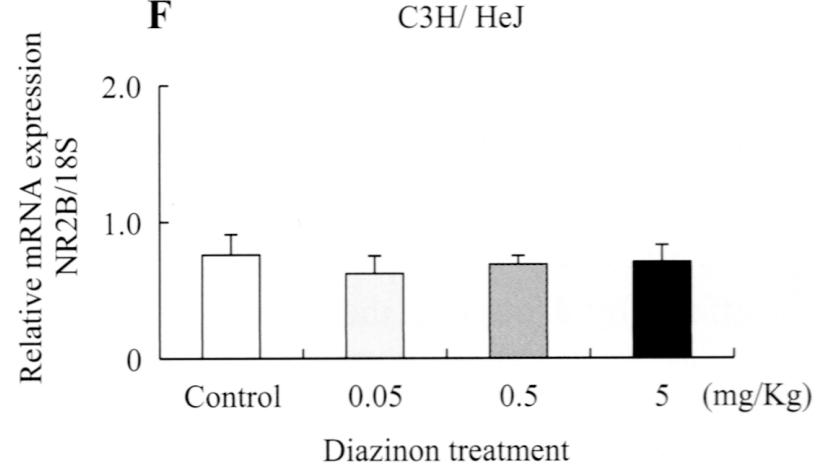

Fig. 3. Memory function-related gene NMDA receptor subunit, A and B: NR1, C and D: NR2A, E and F: NR2B mRNA expression in the hippocampus of the control and diazinon-injected $\mathrm{C} 3 \mathrm{H} / \mathrm{HeN}$ and $\mathrm{C} 3 \mathrm{H} / \mathrm{HeJ}$ mice. Each bar represents the mean \pm S.E. $(n=5)$.

Apoptosis related gene expression in the hippocampus of the control and diazinon-injected mice

To investigate the effect of diazinon injection on apoptosis, the expression of the proapoptotic gene Bax in the hippocampus was examined in the control and diazinon-injected mice. The proapoptotic gene Bax mRNA expression was markedly increased in diazinon-injected $\mathrm{C} 3 \mathrm{H} /$ HeJ mice $(P<0.05$, Fig. 4B). No significant difference was observed between the control and diazinon-injected $\mathrm{C} 3 \mathrm{H} / \mathrm{HeN}$ mice (data not shown). 

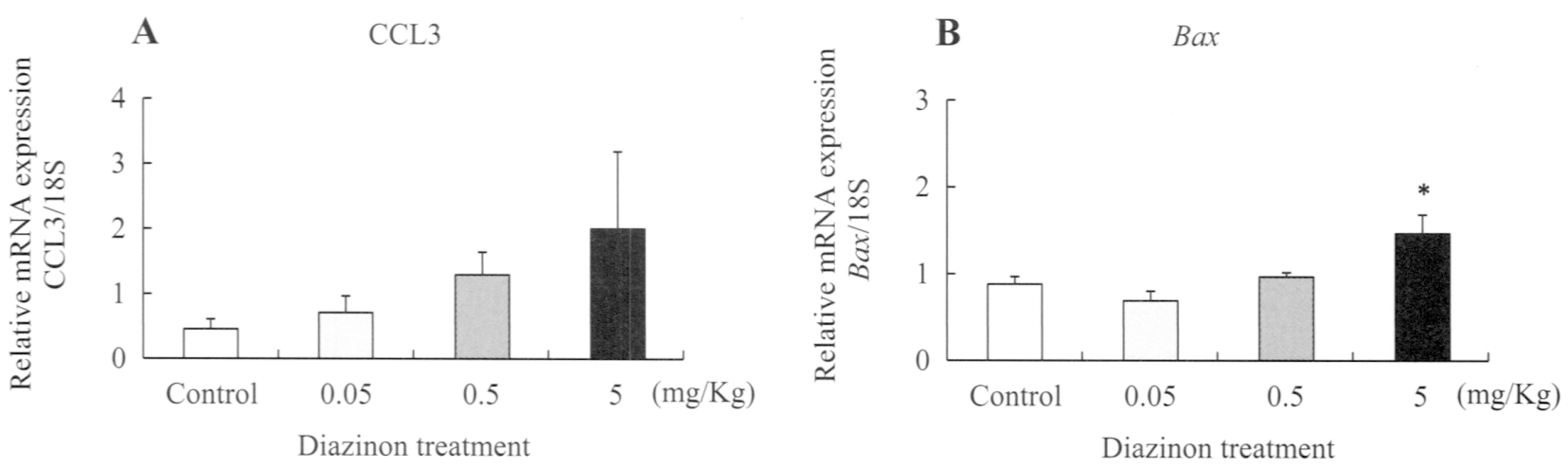

Fig. 4. Proinflammatory chemokine, A: CCL3, and apoptosis-related gene, B: Bax mRNA expression in the hippocampus of the control and diazinon-injected $\mathrm{C} 3 \mathrm{H} / \mathrm{HeJ}$ mice. Each bar represents the mean \pm S.E. (n $=5)(*: P<0.05$, compared with the corresponding vehicle-injected group).

\section{Discussion}

The major finding of the present study was that there were different patterns of hippocampal neurotrophin expression after diazinon exposure in accordance with the presence or absence of TLR4. In the TLR4 intact $\mathrm{C} 3 \mathrm{H} / \mathrm{HeN}$ mice, diazinon exposure did not affect hippocampal neurotrophin expression, whereas in the TLR4 defective $\mathrm{C} 3 \mathrm{H} / \mathrm{HeJ}$ mice diazinon exposure suppressed the expression level of neurotrophin in the hippocampus. To determine the mechanism of TLR4-mediated neurotrophin expression after diazinon injection, we examined neuroinflammation and apoptosis in the $\mathrm{C} 3 \mathrm{H} / \mathrm{HeN}$ and $\mathrm{C} 3 \mathrm{H} / \mathrm{HeJ}$ mice. We observed neuroinflammation and apoptosis in the hippocampus of the diazinon-injected $\mathrm{C} 3 \mathrm{H} / \mathrm{HeJ}$ mice, but not in the $\mathrm{C} 3 \mathrm{H} / \mathrm{HeN}$ mice.

Experimental evidence suggests that environmental toxic chemicals may cause adverse health effects by disrupting the homeostatic regulatory mechanisms of the nervous and immune systems. TLR4 is primarily regarded as an innate immune receptor and it has been commonly attributed to neuroimmune responses in the brain [29]. TLRs also have an innate ability to mediate a rapid response to a wide range of signals in the microenvironment, and not merely to pathogens. Both in vitro and in vivo studies have indicated that TLR4 signaling may contribute to pathogenic changes arising from environmental exposure to toxic chemicals. A previous in vitro study stated that alveolar macrophages produce proinflammatory cytokines, such as TNF- $\alpha$ and IL-6, in response to airborne particulates through TLR2 and 4 [30]. Moreover, the induction of airway hyperresponsiveness after ozone inhalation can reportedly occur through TLR4 [31, 32]. In vivo studies have also shown that TLR4 is necessary for airway inflammation induced by diesel exhaust particles $[33,34]$. Although the role of TLR4 signaling in airway pathogenesis has been extensively demonstrated, the role of TLR4 in brain function after pesticide exposure remains unclear.

The hippocampus is a region of the brain involved in learning and memory processes. Hippocampal neurogenesis occurs throughout the adult lives of mammals, and new neurons in the 
adult hippocampus are generated from the subgranular zone in the dentate gyrus [35]. Recent studies indicate that TLR4 is involved in the hippocampal neurogenesis in adult mice $[36,37]$. Previously, we reported that the NMDA receptor subunit and related protein kinase and transcription factor may act as neurological biomarkers in toluene-induced neurotoxicity [38-40]. Moreover, we demonstrated that neurotrophins and proinflmmatory cytokines are important neuroinflammatory mediators via the TLR4-dependent NF- $\kappa B$ pathway in toluene-induced developmental-phase specific immunotoxicity [27]. However, in the present study, we did not observe any change in NMDA receptor expression after diazinon exposure. These results suggest that different chemicals may act via different signaling pathways to trigger neurotoxic or neuroprotective effects.

Individuals with different immunogenetic backgrounds have different sensitivities to toxic chemical exposure. Previously, we investigated the possible role of the major histocompatibility complex (MHC) locus at the neurotransmitter level in the hippocampi of congenic mice $\left(\mathrm{C} 57 \mathrm{BL} / 10\left[\mathrm{H}-2^{\mathrm{b}}\right]\right.$ and $\left.\mathrm{B} 10 . \mathrm{BR} / \mathrm{Sg}\left[\mathrm{H}-2^{\mathrm{k}}\right]\right)$ following toluene exposure. We found different patterns of glutamate, taurine and glycine levels in both the control and the toluene-treated mice [41]. Recently, our laboratory reported the role of strain differences in sensitivity to low-level toluene exposure on neurotrophins and their receptor levels in the mouse hippocampus in three mouse strains $(\mathrm{C} 3 \mathrm{H} / \mathrm{HeN}, \mathrm{BALB} / \mathrm{c}$ and $\mathrm{C} 57 \mathrm{BL} / 10)$ with or without allergic stimulation. We found that low-level toluene exposure may induce the up-regulation of neurotrophin-related gene expression in the mouse hippocampus, depending on the mouse strain, and that allergic stimulation in sensitive strains may decrease the threshold for sensitivity to a lower exposure level [42]. From these studies, we observed that the $\mathrm{C} 3 \mathrm{H} / \mathrm{HeN}$ strain is more sensitive to chemical exposure compared to the BALB/C and C57BL strains. In the present study, our aim was to investigate the involvement of TLR4 in neurogenesis following diazinon exposure in the chemical sensitive strain. Thus, we selected the TLR4 intact $\mathrm{C} 3 \mathrm{H} / \mathrm{HeN}$ and TLR4 deficient $\mathrm{C} 3 \mathrm{H} / \mathrm{HeJ}$ strain.

Neuroprotective TLR signaling might involve both immune cells and nonimmune cells, such as glia-producing neurotrophic factors [43]. In a brain cell injury model, the activation of TLR4 and NF- $\mathrm{KB}$ may be neuroprotective, either increasing cell resistance or removing toxic molecules via an increase in the phagocytic capacity of activated microglia [1]. However, little is known about the role of TLR4 in neurogenesis following environmental exposure to diazinon. Recently, an in vitro study has reported that apoptosis acts as a specific biomarker of diazinon toxicity in the NTera2/D1 (NT2) cell line [44]. In that study, they showed that low doses of diazinon decrease apoptosis due to homeostatic mechanism and high doses of diazinon increase apoptosis due to direct blockade of acetylcholine receptors [44]. In our present study, TLR4 deficient mice appeared to show a response to diazinon exposure by inducing neuroinflammation and proapoptotic gene expression which may lead to suppression of neurotrophin expression even at a low dose. From our present findings, we suggest that TLR4 may play an important role by modulating neurotrophin levels in adult mice following diazinon exposure. Further studies are needed to explore the exact mechanism of the action of the TLR4-dependent signaling pathway, transcription factors, inflammatory mediators and neuroimmune balance after pesticide exposure. 


\section{Acknowledgements}

This research was partly supported by a grant from the Ministry of Education, Culture, Sports, Sciences, and Technology, Japan (\#21390198) to H. F.

\section{References}

1. Glezer I, Simard AR \& Rivest S (2007): Neuroprotective role of the innate immune system by microglia. Neuroscience 147: 867-883

2. Olson JK \& Miller SD (2004): Microglia initiate central nervous system innate and adaptive immune responses through multiple TLRs. J Immunol 173: 3916-3924

3. Bsibsi M, Persoon-Deen C, Verwer RW, Meeuwsen S, Ravid R \& Van Noort JM (2006): Toll-like receptor 3 on adult human astrocytes triggers production of neuroprotective mediators. Glia 53: 688-695

4. Farina C, Krumbholz M, Giese T, Hartmann G, Aloisi F \& Meinl E (2005): Preferential expression and function of Toll-like receptor 3 in human astrocytes. J Neuroimmunol 159: 12-19

5. Bsibsi M, Ravid R, Gveric D \& van Noort JM (2002): Broad expression of Toll-like receptors in the human central nervous system. J Neuropathol Exp Neurol 61: 1013-1021

6. Lafon M, Megret F, Lafage M \& Prehaud C (2006): The innate immune facet of brain: human neurons express TLR-3 and sense viral dsRNA. J Mol Neurosci 29: 185-194

7. Hoshino K, Takeuchi O, Kawai T, Sanjo H, Ogawa T, Takeda Y, Takeda K \& Akira S (1999): Cutting edge: Toll-like receptor 4 (TLR4)-deficient mice are hyporesponsive to lipopolysaccharide: evidence for TLR4 as the Lps gene product. J Immunol 162: 3749-3752

8. Poltorak A, He X, Smirnova I et al (1998): Defective LPS signaling in C3H/HeJ and C57BL/10ScCr mice: mutations in Tlr4 gene. Science 282: 2085-2088

9. Akira S, Takeda K \& Kaisho T (2001): Toll-like receptors: critical proteins linking innate and acquired immunity. Nat Immunol 2: 675-680

10. Beutler B (2002): Toll-like receptors: how they work and what they do. Curr Opin Hematol 9: 2-10

11. Hayes WJ \& Laws ER (1990): Classes of Pesticides. Handbook of Pesticide Toxicology 3. Academic Press Inc, New York $1576 \mathrm{pp}$

13. Agency for toxic substances and disease registry (ATSDR) 2008: Diazinon CAS \# 333-41-5. Public health statement. http://www.atsdr.cdc.gov/phs/phs.asp?id=511\&tid $=90$

14. Saito I, Onuki A, Seto H \& Uehara S (2003): Determination of organophosphorus pesticides in indoor and outdoor air. J Jpn Soc Atmos Environ 38: 78-88

16. Marshak-Rothstein A (2006): Toll-like receptors in systemic autoimmune disease. Nat Rev Immunol 6: 823-835

17. Beg AA (2002): Endogenous ligands of Toll-like receptors: implications for regulating inflammatory and immune responses. Trends Immunol 23: 509-512

18. McMahon EJ, Bailey SL, Castenada CV, Waldner H \& Miller SD (2005): Epitope spreading initiates in the CNS in two mouse models of multiple sclerosis. Nat Med 11: 335-339

19. Ohashi K, Burkart V, Flohé S \& Kolb H (2000): Cutting edge: heat shock protein 60 is a putative endogenous ligand of the toll-like receptor-4 complex. J Immunol 164: 558-561 
20. Okamura Y, Watari M, Jerud ES, Young DW, Ishizaka ST, Rose J, Chow JC \& Strauss JF (2001): The extra domain A of fibronectin activates Toll-like receptor 4. J Biol Chem 276: 10229-10233

21. Johnson GB, Brunn GJ \& Platt JL (2003): Activation of mammalian Toll-like receptors by endogenous agonists. Crit Rev Immunol 23: 15-44

22. Zola-Morgan S, Squire LR \& Amaral DG (1986): Human amnesia and the medial temporal region: enduring memory impairment following a bilateral lesion limited to field CA1 of the hippocampus. $\mathbf{J}$ Neurosci 6: 2950-2967

23. Mumby DG, Wood ER, Duva CA, Kornecook TJ, Pinel JP \& Phillips AG (1996): Ischemia-induced object-recognition deficits in rats are attenuated by hippocampal ablation before or soon after ischemia. Behav Neurosci 110: 266-281

24. Tsien JZ, Huerta PT \& Tonegawa S (1996): The essential role of hippocampal CA1 NMDA receptordependent synaptic plasticity in spatial memory. Cell 87: 1327-1338

25. Bannerman DM, Good MA, Butcher SP, Ramsay M \& Morris RG (1995): Distinct components of spatial learning revealed by prior training and NMDA receptor blockade. Nature 378: 182-186

26. Win-Shwe TT, Kunugita N, Yoshida Y, Nakajima D, Tsukahara S \& Fujimaki H (2011): Differential mRNA expression of neuroimmune markers in the hippocampus of infant mice following toluene exposure during brain developmental period. J Appl Toxicol doi 10:1002/jat.1643

27. Slotkin TA, Seidler FJ \& Fumagalli F (2007): Exposure to organophosphates reduces the expression of neurotrophic factors in neonatal rat brain regions: similarities and differences in the effects of chlorpyrifos and diazinon on the fibroblast growth factor superfamily. Environ Health Perspect 115: 909-916

28. Win-Shwe TT, Yamamoto S, Ahmed S, Kakeyama M, Kobayashi T \& Fujimaki H (2006): Brain cytokine and chemokine mRNA expression in mice induced by intranasal instillation with ultrafine carbon black. Toxicol Lett 163:153-160

29. Takeda K, Kaisho T \& Akira S (2003): Toll-like receptors. Annu Rev Immunol 21: 335-376

30. Becker S, Fenton MJ \& Soukup JM (2002): Involvement of microbial components and toll-like receptors 2 and 4 in cytokine responses to air pollution particles. Am J Respir Cell Mol Biol 27: 611-618

31. Hollingsworth JW, Cook DN, Brass DM, Walker JK, Morgan DL, Foster WM \& Schwartz DA (2004): The role of Toll-like receptor 4 in environmental airway injury in mice. Am J Respir Crit Care Med 170: $126-132$

32. Garantziotis S, Li Z, Potts EN, Lindsey JY, Stober VP, Polosukhin VV, Blackwell TS, Schwartz DA, Foster WM \& Hollingsworth JW (2010): TLR4 is necessary for hyaluronan-mediated airway hyperresponsiveness after ozone inhalation. Am J Respir Crit Care Med 181: 666-675

33. Takano H, Yanagisawa R, Ichinose T, Sadakane K, Yoshino S, Yoshikawa T \& Morita M (2002): Diesel exhaust particles enhance lung injury related to bacterial endotoxin through expression of proinflammatory cytokines, chemokines, and intercellular adhesion molecule-1. Am J Respir Crit Care Med 165: 1329-1335

34. Inoue K, Takano H, Yanagisawa R, Hirano S, Ichinose T, Shimada A \& Yoshikawa T (2006): The role of toll-like receptor 4 in airway inflammation induced by diesel exhaust particles. Arch Toxicol 80: 275-279

35. Kempermann G, Kuhn HG \& Gage FH (1997): More hippocampal neurons in adult mice living in an enriched environment. Nature 386: 493-495 
36. Rolls A, Shechter R, London A, Ziv Y, Ronen A, Levy R \& Schwartz M (2007): Toll-like receptors modulate adult hippocampal neurogenesis. Nat Cell Biol 9: 1081-1088

37. Keene CD, Chang R, Stephen C, Nivison M, Nutt SE, Look A, Breyer RM, Horner PJ, Hevner R \& Montine TJ (2009): Protection of hippocampal neurogenesis from toll-like receptor 4-dependent innate immune activation by ablation of prostaglandin E2 receptor subtype EP1 or EP2. Am J Pathol 174: $2300-2309$

38. Ahmed S, Tin-Tin-Win-Shwe, Yamamoto S, Tsukahara S, Kunugita N, Arashidani K \& Fujimaki H (2007): Increased hippocampal mRNA expression of neuronal synaptic plasticity related genes in mice chronically exposed to toluene at a low-level human occupational-exposure. Neurotoxicology 28: $168-174$

39. Win-Shwe TT, Tsukahara S, Ahmed S, Fukushima A, Yamamoto S, Kakeyama M, Nakajima D, Goto S, Kobayashi T \& Fujimaki H (2007): Athymic nude mice are insensitive to low-level toluene-induced up-regulation of memory-related gene expressions in the hippocampus. Neurotoxicology 28: 957-964

40. Win-Shwe TT, Kunugita N, Yamamoto S, Arashidani K \& Fujimaki H (2010b): Strain differences influence $\mathrm{N}$-methyl-D-aspartate receptor subunit gene expression in the olfactory bulb of an allergic mouse model following toluene exposure. Neuroimmunomodulation 17: 340-347

41. Win-Shwe TT, Mitsushima D, Yamamoto S, Funabashi T \& Fujimaki H (2009): Strain differences in extracellular amino acid neurotransmitter levels in the hippocampi of major histocompatibility complex congenic mice in response to toluene exposure. Neuroimmunomodulation 16: 185-190

42. Win-Shwe TT, Tsukahara S, Yamamoto S, Fukushima A, Kunugita N, Arashidani K \& Fujimaki H (2010): Up-regulation of neurotrophin-related gene expression in mouse hippocampus following lowlevel toluene exposure. Neurotoxicology 31: 85-93

43. Hanisch UK, Johnson TV \& Kipnis J (2008): Toll-like receptors: roles in neuroprotection? Trends Neurosci 31: 176-182

44. Aluigi MG, Guida C \& Falugi C (2010): Apoptosis as a specific biomarker of diazinon toxicity in NTera2-D1 cells. Chem Biol Interact 187: 299-303 
ダイアジノン投与マウスに誘導された神経毒性へのTLR4の関与

ウィンシュイ・ティンティン ${ }^{1}$, 中島 大介 $^{2}$, 藤巻 秀和 ${ }^{2}$

1 独立行政法人国立環境研究所 環境健康研究センター

2 独立行政法人国立環境研究所 環境リスク研究センター

要旨：海馬における神経栄養因子発現に対するトール様受容体(TLR)4の関与を明らかに するために，ダイアジノンを投与した正常マウス $(\mathrm{C} 3 \mathrm{H} / \mathrm{HeN})$ とTLR4欠陥マウス $(\mathrm{C} 3 \mathrm{H} / \mathrm{HeJ})$ を用い て比較検討した。両マウスにダイアジノンを毎週 1 回, 3 回の投与を行い, 海馬に㧍ける神経栄養 因子産生をリアルタイムRT-PCRで測定した。その結果, C3H/HeNマウスではダイアジノン投与の 影響はみられなかったが, C3H/HeJマウスではnerve growth factor (NGF) と brain-derived neurotrophic factor $(\mathrm{BDNF})$ 遺伝子発現の低下が認められた。 さらに, ダイアジノンを投与したC $3 \mathrm{H} / \mathrm{HeJ}$ マウス ではCCL3ケモカイン遺伝子発現の増加傾向とアポトーシス関連Bax 遺伝子発現の顕著な増加が 見られた．本研究結果は, TLR4シグナル経路に欠陥があるとダイアジノン投与の影響を受けやす いことを示唆している。

キーワード：トール様受容体 4 , ダイアジノン, 神経栄養因子, 神経毒性, 海馬.

J UOEH（産業医大誌）34（1）：1 - 13（2012） 